\title{
PENGARUH PENGENDALIAN BIAYA BAHAN BAKU PEMBUATAN KAROSERI TYPE KENDARAAN ANGKUTAN KOTA TERHADAP HARGA POKOK PESANAN PADA PT. BUMI BOSOWA INTERNATIONAL
}

\author{
Yudin Wahyudin \\ STMIK Rosma Karawang, Sistem Informasi \\ yudinwahyudin78@yahoo.co.id
}

\begin{abstract}
ABSTRAK
Pengendalian biaya bahan baku dalam sebuah proses produksi mutlak diperlukan, tanpa adanya pengendalian dikhawatirkan akan terjadinya pemborosan pemakaian bahan baku. Tujuan dari pengendalian bahan baku adalah agar bahan baku yang dipakai sesuai dengan standar yang telah ditetapkan oleh pihak perusahaan. Selain itu pengendalian yang dilakukan bertujuan agar terjadinya efesiensi dalam pemakaian bahan baku. Penelitian ini dilakukan untuk mengetahui pengendalian biaya bahan baku yang dilakukan di PT. Bumi Bosowa International, penentuan harga pokok pesanan dan pengaruh biaya bahan baku terhadap harga pokok pesanan. Metode yang digunakan dalam melakukan penelitian ini adalah dengan menggunakan metode deskriptif, metode pengambilan data dilakukan dengan melakukan observasi dan wawancara, sedangkan metode pengolahan data digunakan beberapa analisis yaitu : analisis regresi, analisis korelasi, koefisien determinasi dan analisis uji t.
\end{abstract}

Kata Kunci : Pengendalian, Biaya Bahan Baku, Harga Pokok Pesanan

\section{Abstract}

Controlling the cost of raw materials in a production process is absolutely necessary, without any control is feared will waste of raw material usage. The purpose of the control of this raw materials is so that the row materials used in accordance with the standars set by company. Besides that the control is done to make efficiency in the use of raw materials. This research is done to know the control of raw material cost which done in PT. Bumi Bosowa International, the determination of the cost of order and the influence of the cost of raw materials on the cost of the order. The method used in doing this research is by using descriptive method, data retrieval method is done by observation and interview, while data processing method used some analysis that is: regression analysis, correlation analysis, coefficient of determination and t test analysis.

Keywords: Control, Cost of Raw Materials, Cost of Order 


\section{PENDAHULUAN}

Dampak terjadinya sebuah proses produksi pada sebuah perusahaan baik skala kecil maupun besar adalah munculnya biaya bahan baku. Dalam dunia usaha biaya merupakan salah satu komponen untuk menunjang lancarnya sebuah proses produksi dalam sebuah perusahaan yang tidak dapat dihindarkan.

Penentu sebuah keberhasilan operasional pada perusahaan, diperlukan sebuah strategi dan taktik untuk mengendalikan biaya ketika perusahaan tersebut mempunyai sebuah keinginan untuk dapat bertahan dan bersaing dengan perusahaan lainnya, keinginan yang lain dari sebuah perusahaan adalah dapat berkembang dan maju dengan pesat. Menjadi sebuah kewajaran apabila perusahaan tersebut gagal dalam mengendalikan biaya makan yang akan terjadi keborosan, dan tidak hanya itu perusahaan tersebut akan mengalami kerugian yang berakibat fatal terhadap bangkrutnya perusahaan tersebut.

Operasional perusahaan pada umumnya terbagi menjadi dua proses produksi yang dilakukan, yaitu dengan cara proses produksi berdasarkan pesanan dan proses produksi berdasarkan kebutuhan pasar. Pada perusahaan yang berproduksi berdasarkan pesanan, yang tentu saja dalam proses pengumpulan harga pokok produksinya menggunakan metode harga pokok pesanan atau Job Order Cost Method.

Job Order Cost Method atau metode harga pokok pesanan produksi yang diterapkan pada sebuah perusahaan dilakukan dengan cara mengumpulkan biayabiaya produksi pesanan barang tertentu dan harga pokok satuan produk yang dihasilkan tersebut dihitung dengan cara membagi seluruh biaya dengan jumlah satuan produk pesanan yang dihasilkan.

Perusahaan dalam menghasilkan sebuah produk, sebuah perusahaan biasanya tidak hanya mengeluarkan satu macam biaya produksi, perusahaan yang bergerak dalam bidang manufakkur berbagai macam yang dikeluarkan dikelompokkan kedalam tiga kategori yaitu biaya bahan baku, biaya tenaga kerja langsung dan biaya overhead pabrik. Dari ketiga kategori biaya tersebut biaya bahan baku merupakan salah satu faktor penentu dalam tercapainya proses produksi pada sebuah perusahaan. Untuk menunjang lancarnya proses produksi tersebut, yang tidak menutup kemungkinan pihak manajemen menghadapi berbagai kendala dalam proses penyediaan bahan baku tersebut, biasanya faktor keterlambatan dalam penyediaan bahan baku merupakan faktor yang menjadi hambatan utama dalam kelancaran proses produksi. Selain lambatnya proses penyediaan bahan baku, penyediaan bahan baku yang terlalu berlebihanpun akan mengalami kendala yang akan berakibat terjadinya keborosan modal kerja pada sebuah perusahaan.

Sebuah perusahaan dalam proses pengadaan dan penyimpanan bahan baku yang terlalu berlebihan, maka akan muncul permasalahan dalam menentukan harga pokok bahan baku yang dibeli, sedangkan bila bahan baku yang berlebih tersebut dipakai maka akan muncul masalah dalam menentukan harga pokok bahan baku yang terpakai. Indikasi tersebut menunjukkan bahwa ketika pengendalian bahan baku tidak dilakukan dengan ketat maka yang terjadi adalah akan berpengaruh langsung terhadap besarnya harga pokok pesanan, dan tidak menutup kemungkinan menyebabkan kerugian.

\section{TINJAUAN PUSTAKA}

\section{Pengertian Akuntansi Biaya}

Menurut Abdul Halim (1999:3), "akuntansi biaya adalah akuntansi yang membicarakan tentang penentuan harga pokok (cost) dari "sesuatu produk" yang diproduksi (atau dijual dipasar) baik untuk memenuhi pesanan dari pemesan maupun untuk menjadi persediaan barang dagangan yang akan dijual".

\section{Pengertian Biaya}

Menurut Mulyadi (1999:8-9), "biaya adalah pengorbanan sumber ekonomi yang di ukur dalam satuan uang, yang telah terjadi atau yang kemungkinan akan terjadi untuk tujuan tertentu". 


\section{Pengendalian Biaya Bahan Baku}

Menurut R.A Supriyono (1999:8), "pengendalian adalah proses untuk memeriksa kembali, menilai dan selalu memonitor laporan-laporan apakah pelaksanaan tidak menyimpang dari tujuan yang sudah ditentukan. Dalam mengadakan pengendalian harus diadakan komparasi (perbandingan) antara hasil sesungguhnya yang dicapai dengan proyeksi yang ditetapkan dalam perencanaan".

Bentuk salah satu pengendalian dapat dilakukan dengan mengadakan pemeriksaan internal, yang merupakan aktivitas penilaian independen yang ada didalam organisasi perusahaan, yang bertujuan untuk melihat kembali dan menyelenggarakan pengawasan manajemen yang efektif dan cukup memadai atas pencatatan akuntansi, keuangan produksi dan kegiatan lainnya didalam perusahaan.

Menurut Abdul Halim (1999:39), "bahan baku adalah merupakan bahan yang secara menyeluruh membentuk produk selesai dan dapat diidentifikasikan secara langsung pada produk yang bersangkutan".

Menurut R.A Supriyono (1999:20), "bahan baku adalah bahan yang akan di olah menjadi bagian produk selesai dan pemakaiannya dapat diidentifikasikan atau di ikuti jejaknya atau merupakan bagian integral pada produk tertentu".

Pengertian bahan baku dapat meluas meliputi bahan-bahan yang digunakan untuk memperlancar proes produksi. Bahan baku yang demikian termasuk dalam pengertian bahan baku penolong atau bahan baku pembantu. Bahan baku dibedakan menjadi dua yaitu bahan baku langsung dan bahan baku tidak langsung, bila biaya bahan baku tersebut langsung dibebankan kepada kelompok biaya bahan baku dinamakan bahan baku langsung, sedangkan bila biaya bahan baku dimaksud dibebankan melalui rekening biaya over head pabrik dinamakan biaya bahan baku tidak langsung.

Bahan baku yang diolah dalam perusahaan manufaktur dapat diperoleh dari pembelian lokal, import atau dari pengolahan sendiri. Didalam memperoleh bahan baku, perusahaan tidak hanya mengeluarkan biaya pembelian, pergudangan dan biaya-biaya perolehan yang lain.

\section{Harga Pokok Pesanan}

Menurut R.A Supriyono (1999:36), "secara ekstrim pola pengumpulan harga pokok dapat dikelompokkan menjadi dua metode yaitu metode harga pokok pesanan dan harga pokok proses. Penetapan harga pokok tersebut pada suatu perusahaan tergantung pada sifat atau karakteristik pengolahan bahan menjadi produk selesai yang akan mempengaruhi metode pengumpulan harga pokok yang digunakan".

\section{Harga Pokok Pesanan (Job Order Cost Method).}

Adalah metode pengumpulan harga pokok dimana biaya dikumpulkan untuk setiap pesanan atau kontrak atau jasa secara terpisah, dan setiap pesanan atau kontrak dapat dipisahkan identitasnya. Pada harga pokok pesanan, harga pokok dikumpulkan untuk setiap pesanan, jumlah biaya produksi setiap pesanan, jumlah biaya produksi setiap pesanan akan dihitung pada saat pesanan selesai. Untuk menghitung biaya satuan, jumlah biaya produksi pesanan tertentu dibagi jumlah produksi pesanan yang bersangkutan.

2. Harga Pokok Proses (Process Cost Method)

Adalah metode pengumpulan harga pokok produk dimana biaya dikumpulkan untuk setiap satuan waktu tertentu. Penerapan metode ini biasanya pada perusahaan yang menghasilkan produk yang homogen, bentuk produk bersifat standar dan tidak tergantung spesifikasi yang diminta oleh pembeli. Kegiatan produksi ditentukan oleh budget produksi atau skedul produksi untuk satuan waktu tertentu yang sekaligus dipakai dassar oleh bagian produksi untuk melaksanakan produksi.

Menurut Mulyadi (1991:41), "karakteristik usaha prusahaan yang produksinya berdasarkan pesanan berpengaruh terhadap pengumpulan biaya produksinya". Metode pengumpulan biaya produksi dengan metode harga pokok pesanan yang digunakan dalam perusahaan yang produksinya berdasarkan pesanan memiliki karakteristik sebagai berikut : 
1. Perusahaan memproduksi berbagai macam produk sesuai dengan spesifikasi pemesan dan setiap jenis produk perlu dihitung harga pokok produksinya secara individual.

2. Biaya produksi harus digolongkan berdasarkan hubungannya dengan produk menjadi dua kelompok yaitu biaya produksi langsung dan biaya produksi tidak langsung.

3. Biaya produksi langsung terdiri dari biaya bahan baku dan biaya tenaga kerja langsung, sedangkan biaya produksi tidak langsung disebut dengan biaya overhead pabrik.

4. Biaya produksi langsung diperhitungkan sebagai harga pokok pesanan tertentu berdasarkan biaya yang sesungguhnya terjadi, sedangkan biaya overhead pabrik diperhitungkan ke dalam harga pokok pesanan berdasarkan tarif yang ditentukan dimuka. Harga pokok produksi per unit dihitung pada saat pesanan selesai diproduksi dengan cara membagi jumlah biaya produksi yang untuk pesanan tersebut dengan jumlah unit produk yang dihasilkan dalam pesanan yang bersangkutan.

\section{Perbedaan Harga Pokok Pesanan Dengan Harga Pokok Proses}

Menurut Mulyadi (1991:70), "perbedaan antara pengumpulan biaya produksi metode harga pokok pesanan dan harga pokok proses terletak pada :

1. Pengumpulan biaya produksi.

2. Perhitungan harga pokok produksi per satuan.

3. Penggolongan biaya produksi

4. Unsur biaya yang dikelompokkan dalam biaya overhead pabrik.

\section{METODE PENELITIAN}

Penelitian ini menggunakan metode deskriptif yaitu metode yang memaparkan pelaksanaan pengendalian biaya bahan baku, penentuan harga pokok pesanan serta berapa besar pengaruh pengendalian biaya bahan baku type kendaraan angkutan kota terhadap harga pokok pesanan.

\section{Variabel Penelitian}

Penelitian ini menggunakan 2 (dua) buah variabel yaitu variabel bebas dan variabel terikat. Yang menjadi variabel bebas dalam penelitian ini adalah biaya bahan baku sedangkan yang menjadi variabel terikat adalah harga pokok pesanan.

Tabel. 1 Variabel Penelitian

\begin{tabular}{|c|c|}
\hline Variabel & Sub Variabel \\
\hline $\begin{array}{l}\text { Variabel bebas (X) } \\
\text { Biaya Bahan Baku }\end{array}$ & $\begin{array}{lr}\text {-Penentuan } & \text { harga } \\
\text { perolehan } & \text { bahan } \\
\text { yang dibeli. } & \\
\text {-Penentuan Harga } \\
\text { Pokok bahan yang } \\
\text { dipakai dalam } \\
\text { pengolahan produk }\end{array}$ \\
\hline $\begin{array}{lr}\text { Variabel terikat }(\mathrm{Y}) \\
\text { Harga } & \text { Pokok } \\
\text { Pesanan } & \end{array}$ & $\begin{array}{l}\text {-Jumlah produk } \\
\text { yang dipesan } \\
\text {-Total } \\
\text { produksi }\end{array}$ \\
\hline
\end{tabular}

Sumber : Akuntansi biaya (Supriyono:1999)

\section{Metode Pengumpulan Data}

Peneliti menganalisa masalah yang akan dibahas dalam penelitian ini, diantaranya data yang diperlukan berupa data primer dan data sekunder.

1. Data primer, adalah data yang diperoleh dengan cara melakukan wawancara, yaitu tanya jawab langsung dengan pihak yang berkompeten dalam hal ini adalah bagian HPP. Selain wawancara data juga diperoleh dengan cara observasi, yaitu melakukan pengamatan dan pencatatan data secara sistematis yang terjadi di perusahaan.

2. Pengumpulan data sekunder, data ini diperoleh dengan cara mengolah data primer yang disajikan dalam bentuk angka dan grafik ditambah dari berbagai buku sebagai referensinya.

\section{Metode Analisis Data}

Penelitian ini menggunakan beberapa metode analisis data, antara lain :

1. Analisis kualitatif, adalah analisis yang berusaha menerangkan dan menjelaskan hasil penelitian mengenai objek yang di observasi dengan data yang diperoleh berdasarkan teori pendapat serta pandangan. 
2. Analisis kuantitatif, analisis ini dipergunakan untuk mengetahui secara jelas pengendalian bahan baku yang diterapkan :

a. Dalam menentukan harga pokok bahan yaitu dengan cara menambahkan harga pokok dengan biaya-biaya lain seperti biaya yang menyangkut biaya pengangkutan dan penyimpanan.

b. Untuk menentukan harga pokok pesanan digunakan metode harga pokok pesanan dengan pendekatan biaya penuh (Full Costing).

c. Dalam menghitung nilai persediaan bahan digunakan dengan sistem FIFO (First In First Out)

d. Analisis korelasi, digunakan untuk mengetahui kuat atau tidaknya hubungan biaya bahan baku terhadap harga pokok pesanan sebagaimana dalam buku Sri Mulyono (1998:211), rumus yang digunakan adalah sebagai berikut :

$$
\mathrm{r}=\frac{\mathrm{n} \sum \mathrm{XY}-\sum \mathrm{X} \cdot \sum \mathrm{Y}}{\sqrt{\mathrm{n}\left(\sum \mathrm{X}^{2}-\left(\sum \mathrm{X}\right)^{2} \cdot \mathrm{n}(\mathrm{Y})^{2}-\left(\sum \mathrm{Y}\right)^{2}\right.}}
$$

Keterangan :

$r=$ Koefisien korelasi

$\mathrm{X}=$ Variabel viaya bahan baku

$\mathrm{Y}=$ Variabel harga pokok pesanan

$\mathrm{n}=$ periode koefisien korelasi terletak antara batasan $-r+1$

$\mathrm{r}=+1$, berarti terdapat pengaruh yang searah atau positif sempurna antara variabel $X$ dan variabel $Y$

$r=-1$, berarti terdapat pengaruh yang berlawanan arah atau negatif sempurna antara variabel $\mathrm{X}$ dan variabel $\mathrm{Y}$

$r=0$, berarti tidak ada pengaruh anatara variabel $\mathrm{X}$ dan variabel $\mathrm{Y}$

e. Analisis Determinasi.

Analisis ini digunakan untuk mengetahui pengaruh biaya bahan baku terhadap harga pokok pesanan yang dinyatakan dengan prosentase. Rumus yang digunakan dalam buku Sri Mulyono (1998:213), sebagai berikut:

$$
\mathrm{KD}=\mathrm{r}^{2} \mathrm{X} 100 \%
$$

f. Analisis Uji t

Analisis uji $t$ test digunakan untuk membuktikan apakah hasil korelasi yang diperoleh itu secara kebetulan atau memang ada pengaruh biaya bahan baku terhadap harga pokok pesanan. Rumus yang dipergunakan dalam buku Sri Mulyono (1998:213), sebagai berikut :

Langkah-langkah pengujian :

a. Menyusun formula Ho dan $\mathrm{Hi}$

Ho $: r=0$, berarti tidak ada pengaruh antara variabel $\mathrm{X}$ dan variabel $\mathrm{Y}$

Hi $: r>0$, berarti terdapat pengaruh positif antara variabel $X$ dan variabel $\mathrm{Y}$ alternatif pengujian dengan sisi kanan.

b. Menentukan $\mathrm{t}$ tabel pada level of significant $(\mathrm{a})=5 \%$

c. Menentukan t hitung dengan rumus :

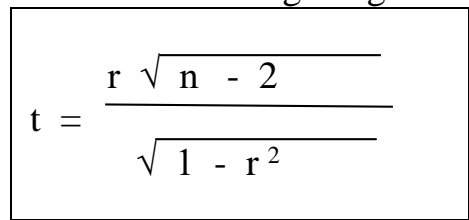

$$
\begin{aligned}
& \text { Dimana : } \\
& \mathrm{r}=\text { koefisien korelasi } \\
& \mathrm{n}=\text { jumlah test }
\end{aligned}
$$

d. Kriteria pengujian :

Dengan derajat kebebasan $=\mathrm{n}-2$

Ho diterima apabila : $\mathrm{t}$ hitung $<\mathrm{t}$ tabel.

Ho ditolak apabila : $\mathrm{t}$ hitung $>\mathrm{t}$ tabel

e. Kesimpulan Hipotesis

Kesimpulan apakah Ho diterima atau di tolak.

\section{HASIL DAN PEMBAHASAN}

\section{Pelaksanaan Pengendalian Biaya Bahan Baku pada Type Kendaraan Angkutan Kota di PT. Bumi Bosowa International}

Pengendalian dalam konteks ini bagaimana mengetahui pelaksanaan pekerjaan karyawan borongan dalam sebuah proses produksi mulai tahapan body sampai finishing. Dalam pelaksanaanya dilapangan sering ditemui bahwa pengambilan material atau bahan baku melebihi dari standar bahan baku yang telah ditentukan oleh perusahaan.

Kemudian untuk mengetahui lebih lanjut tentang pengendalian biaya bahan baku dalam pembuatan karoseri mobil type 
angkutan kota dapat dilihat pada tabel 1 berikut :

Tabel 1

Pengendalian Biaya Bahan Baku Pembuatan

Kendaraan Angkutan Kota

\begin{tabular}{|c|c|c|l|l}
\hline Tahun & Total Biaya Standar & Total Biaya Realisasi & Selisih & Keteran \\
\hline 2002 & 3.456 .044 .00 & 3.197 .526 .50 & 258.517 .50 & \\
\hline 2003 & 2.792 .593 .10 & 3.007 .740 .10 & 215.147 .00 & \\
\hline 2004 & 3.268 .948 .50 & 3.450 .675 .00 & 181.726 .50 & \\
\hline 2005 & 3.521 .870 .50 & 3.924 .225 .00 & 402.354 .50 & \\
\hline 2006 & 4.079 .657 .50 & 4.340 .007 .50 & 260.350 .00 & \\
\hline
\end{tabular}

Sumber : PT. Bumi Bosowa Int'1 2006

Tabel 1 Pengendalian Biaya Bahan Baku Pembuatan Kendaraan Angkutan Kota, dapat diketahui bahwa biaya bahan baku standar yang ditetapkan oleh PT. Bumi Bosowa International pada tahun 2002 dibandingkan dengan biaya bahan baku sebenarnya maka secara umum, biaya bahan baku realisasi atau sebenarnya lebih kecil dibandingkan dengan biaya bahan baku standar. Hal tersebut dapat diketahui dengan melihat besarnya selisih lebih yang terjadi antara biaya bahan baku yang sebenarnya secara keseluruhan yaitu sebesar Rp. 258.517.50,-. Dengan demikian bahwa pengendalian biaya bahan baku pada tahun 2002 dapat dikatakan efisien.

Sedangkan pada tahun 2003 biaya bahan baku yang ditetapkan secara umum dapat dijelaskan bahwa biaya bahan baku standar lebih kecil dibandingkan dengan biaya bahan baku realisasi atau yang sebenarnya. Hal tersebut dapat dilihat dari besarnya selisih kurang antara biaya bahan baku standar dengan biaya bahan baku yang sebenarnya sebesar Rp. 215.147.00,- dengan demikian bahwa pengendalian biaya bahan baku pada tahun 2003 adalah tidak efisien. Begitupun yang terjadi pada tahun 2004, 2005 dan tahun 2006.

PT. Bumi Bosowa International, dengan demikian penetapan besarnya biaya bahan baku standar lebih kecil dibandingkan dengan besarnya biaya bahan baku yang sebenarnya hal tersebut dapat diketahui dari data yang ditampilkan penulis, menurut pengamatan penulis dan penelitian penulis hal tersebut terjadi karena adanya harga bahan baku yang bersifat fluktuatif atau berubah-ubah, skill individual tenaga kerja yang berbeda-beda, kualitas bahan baku yang kurang bagus dan tidak memenuhi standar yang telah ditetapkan, serta adanya perubahan bentuk model atau pesanan khusus.

Penelitian ini dilakukan untuk mengetahui pengaruh biaya bahan baku terhadap harga pokok pesanan, maka perlu dilakukan beberapa pengujian, diantaranya dengana menggunakan analisa regresi, korelasi, koefisien determinasi, dan uji $\mathrm{T}$, pengujian hipotesis menggunakan alat bantu analisis SPSS, dengan mengacu pada data sebagai berikut :

Tabel 2.

Biaya bahan baku dan harga pokok pesanan

\begin{tabular}{|c|c|c|c|}
\hline No & Tahun & $\begin{array}{c}\text { Biaya Bahan } \\
\text { Baku X } \\
\text { (Ribuan) }\end{array}$ & $\begin{array}{c}\text { Harga Pokok } \\
\text { Pesanan Y } \\
\text { (Ribuan) }\end{array}$ \\
\hline 1 & 2002 & $3.197 .526,50,-$ & $3.926 .378 .81,-$ \\
\hline 2 & 2003 & $3.007 .740 .10,-$ & $3.694 .615 .10,-$ \\
\hline 3 & 2004 & $3.450 .675 .00,-$ & $4.210 .593 .90,-$ \\
\hline 4 & 2005 & $3.924 .225 .00,-$ & $4.947 .846 .43,-$ \\
\hline 5 & 2006 & $4.340 .007,50,-$ & $5.471 .488 .93,-$ \\
\hline \multicolumn{2}{|c|}{ Jumlah } & $\mathbf{1 7 . 9 2 0 . 1 7 4 . 1 0 , -}$ & $\mathbf{2 2 . 2 5 0 . 9 2 3 . 1 6 , -}$ \\
\hline
\end{tabular}

Sumber : PT. Bumi Bosowa Int'1, Tahun 2006

\section{Analisa Regresi}

Analisa ini digunakan untuk mengetahui antara varibel $(\mathrm{X})$ dan harga pokok pesanan (Y)

Tabel.3 Analisa Regresi Coefficients ${ }^{2}$

\begin{tabular}{|c|c|c|c|c|c|}
\hline \multirow{2}{*}{ Model } & \multicolumn{2}{|c|}{$\begin{array}{l}\text { Unstandardized } \\
\text { Coefficients }\end{array}$} & \multirow{2}{*}{$\begin{array}{l}\text { Standardized } \\
\text { Coefficients } \\
\text { Beta }\end{array}$} & \multirow{2}{*}{$\mathrm{t}$} & \multirow{2}{*}{ Sig } \\
\hline & B & $\begin{array}{l}\text { Std. } \\
\text { Error }\end{array}$ & & & \\
\hline $\begin{array}{l}1 \\
\text { (Constan) }\end{array}$ & -416725 & 1415589 & & $\begin{array}{c}- \\
2.943 \\
\end{array}$ & 60 \\
\hline $\begin{array}{l}\text { Bahan } \\
\text { Baku }\end{array}$ & 1.358 & 0.39 & 999 & 34.69 & 0 \\
\hline
\end{tabular}

a.Dependent variable: Harga Pokok Pesanan

Berdasarkan hasil dari analisis diperoleh konstanta sebesar koefisien regresi $X$ sebesar 1.358 sehingga persamaan regresi : $\mathrm{Y}=1.358$ $\mathrm{X}$, artinya koefisien regresi sebesar 1.357 , menyatakan bahwa setiap penambahan biaya bahan baku sebesar Rp. 1 Ribu (karena satuan biaya dalam ribu rupiah) akan meningkatkan besarnya harga pokok pesanan sebesar 1.357 Rupiah. 


\section{Analisa Korelasi}

Analisa korelasi dipergunakan untuk mengetahui ukuran kekuatan (derajat hubungan) antara variabel biaya bahan baku (X) dan variabel harga pokok pesanan (Y)

Tabel.4 Analisa Korelasi Model Summary

\begin{tabular}{|c|c|c|c|c|c|}
\hline \multirow{2}{*}{ Model $\mathrm{R}$} & \multirow{2}{*}{ R Square. } & \multirow{2}{*}{ Adjusted R Square } & \multirow{2}{*}{ Std. Error of the estimate } & \multicolumn{2}{|c|}{\begin{tabular}{|c|} 
Change Statisiciss \\
\end{tabular}} \\
\hline & & & & R Square Chang & 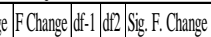 \\
\hline 199 & \begin{tabular}{l|l}
9 & 996
\end{tabular} & 997 & 42640.23667 & 998 & \begin{tabular}{|l|l|l|}
1203.36 & 1 & 3 \\
\end{tabular} \\
\hline
\end{tabular}

a.Predictors: (Constant) Biaya Bahan Baku

Berdasarkan analisa diatas maka diperoleh koefisien korelasi sebesar 0.999 yang berarti bahwa hubungan antara biaya bahan baku dengan harga pokok pesanan sangat kuat dan searah, ini berarti bahwa jika variable bebas (X) biaya bahan baku naik, maka variabel terikat $(\mathrm{Y})$ harga pokok pesanan juga ikut naik.

\section{Koefisien Determinasi.}

Koefisien Determinasi digunakan untuk melihat besarnya determinasi prosentase (\%) variable bahan baku (X) mempengaruhi harga pokok pesanan (Y). Berdasarkan analisis diperoleh nilai koefisien determinasi sebesar (CD) $99.8 \%$ yang berarti biaya bahan baku mempengaruhi harga pokok pesanan sebesar $99.8 \%$.

\section{Analisa Uji T}

Berdasarkan hasil analisa diperoleh $t$ hitung sebesar 34.689 yang lebih besar dari t table sebesar 2.353, dengan demikian diperoleh t table terletak di daerah penolakan Ho. Dilihat dari hasil diatas maka berarti hubungan antara biaya bahan baku dengan harga pokok pesanan adalah signikan dan bukan merupakan sebuah faktor kebetulan.

\section{PEMBAHASAN HASIL PENELITIAN}

Hasil penelitian ini bahwa biaya bahan baku mempunyai pengaruh yang sangat kuat dan positif terhadap harga pokok pesanan dengan koefisien korelasi sebesar 0.999 yang signifikan pada koefisien determinasi sebesar 99.8\%. Sehingga dapat disimpulkan bahwa biaya bahan baku mempengaruhi besarnya harga pokok pesanan pada PT. Bumi Bosowa International.

Komposisi utama yang membentuk harga pokok pesanan adalah biaya bahan baku, biaya tenaga kerja langsung dan biaya overhead pabrik.

Hal ini sangatlah relevan dengan hasil penelitian yang telah dilakukan, serta hasil penelitian ini juga selaras dengan teori yang telah dikemukakan oleh Mulyadi (1999:295) dimana bahan baku merupakan bahan yang membentuk secara keseluruhan pada produk jadi.

David Doyle (1996:5) mengatakan, "komponen utama yaitu bahan baku merupakan yang terbesar dalam membentuk harga pokok pesanan sehingga bisa mencapai sebesar $50 \%$ dari total biaya pabrikasi saat ini, biaya tenaga kerja langsung rata-rata hanya $15 \%$ dan biaya overhead umum lebih dari $30 \%$.

\section{KESIMPULAN DAN SARAN}

\section{Kesimpulan}

Seluruh pembahasan dan setelah melakukan analisis serta pembahasan dari penelitian dapatlah kiranya ditarik kesimpulan sebagai berikut :

1. Untuk menentukan harga pokok pesanan dengan cara menjumlahkan semua kompenen biaya bahan baku, biaya tenaga kerja langsung, biaya overhead pabrik dan biaya-biaya lainnya, dan berdasarkan perhitungan diatas maka besarnya harga pokok pesanan realisasi untuk type kendaraan angkutan kota pada tahun 2006 adalah sebesar Rp. 5.471.488.93,-

2. Berdasarkan hasil perhitungan dan analisis maka diperoleh koefisien regresi $\mathrm{X}$ sebesar 1.357 sehingga diperoleh persamaan regresi : $\mathrm{Y}=+1.357 \mathrm{X}$, hasil analisis diperoleh koefisien korelasi sebesar 0.999 yang menunjukkan bahwa hubungan antara biaya bahan baku dan harga pokok pesanan sangat kuat dan searah. Hasil pengujjian determinasi diperoleh angka sebesar $99.8 \%$ sehingga dapat disimpulkan bahwa biaya bahan baku mempengaruhi besarnya harga pokok pesanan di PT. Bumi Bosowa International sebesar $99.8 \%$ sedangkan pada pengujian significant $(\mathrm{t})$ diperoleh $\mathrm{t}$ 
hitung sebesar sebesar 34.689 yang lebih besar dari $t$ table sebesar 2.353 berdasarkan kriteria pengujian maka terdapat hubungan positif antara biaya abahan baku dengan harga pokok pesanan.

\section{Saran}

Setelah melakukan penelitian pada PT. Bumi Bosowa International saran untuk pihak perusahaan adalah sebagai berikut :

1. Hasil penelitian ini bisa dijadikan sebagai bahan rujukan atau referensi bagi pihak perusahaan dalam menentukan standarisasi biaya bahan baku dan melakukan peninjauan kembali terhadap standarisasi yang telah ditetapkan terutama untuk biaya bahan baku type kendaraan angkutan kota.

2. Faktor yang menyebabkan terjadinya selisih pada biaya bahan baku antara lain disebabkan karena adanya harga bahan baku yang bersifat fluktuatif atau berubah-rubah, skill individual tenaga kerja borongan yang berbeda-beda, kualitas bahan baku yang kurang bagus dan tidak memenuhi standar yang telah ditetapkan serta adanya perubahan bentuk model atau pesanan khusus.

3. Dalam menentukan biaya bahan baku standar pihak perusahaan sebaiknya lebih realistis dalam menyusun standarisasi biaya bahan baku sesuai dengan kondisi harga-harga material dipasaran sehingga standarisasi yang dilakukan tidak terlalu kurang dengan biaya bahan baku yang sesungguhnya ataupun terlalu berlebihan dengan biaya bahan baku realisasi.

\section{DAFTAR PUSTAKA}

Abdul Halim, 1999, Dasar-Dasar Akuntansi Biaya. Edisi Keempat. Penerbit BPFE Yogyakarta, Yogyakarta.

Bambang Riyatno, 1993, Dasar-Dasar Pembelanjaan Perusahaan. Yayasan
Badan Penerbit Gadjah Mada, Yogyakarta

David Doyle, 1996. Pengendalian Biaya Pedoman Strategis. Cetakan Pertama. Penerbit PT. Pustaka Binaman Pressindo. Jakarta

Gayle L Rayburn, 1999. Akuntansi Biaya dengan Menggunakan Pendekatan Manajemen Biaya. Edisi Keenam. Penerbit Erlangga Jakarta.

Haryono Jusup AL.1994, Dasar-Dasar Akuntansi, Edisi Keempat, Penerbit, Bagian Penerbitan Sekolah Tinggi Ilmu Ekonomi YKPN. Yogyakarta.

Milton F. Usry, Lawrence H. Hammer, 1997. Akuntansi Biaya Perencanaan dan Pengendalian. Edisi kesepuluh. Penerbit Erlangga Jakarta.

Mulyadi, 1999, Akuntansi Biaya. Edisi kelima. Penerbit Aditya Media Yogyakarta.

Supriono, R.A, 1999. Akuntansi Biaya: Pengumpulan Biaya dan Penentuan Harga Pokok. Edisi kedua. Penerbit BPFE Yogyakarta.

Sri Mulyono, 1998. Statistika Untuk Ekonomi. Edisi Revisi, FEUI Jakarta.

Sugiono, 2002. Statistika Untuk Penelitian. Cetakan Keempat. Penerbit Alfabeta, Bandung

Usman Husaini, 2000. Pengantar Statistika. Cetakan kedua. Penerbit Bumi Aksara Jakarta.

Uus MD Fadli, 2002. Metodologi Penelitian. Hand Out Fakultas Ekonomi Unsika, Karawang.

Yogia Sembiring, Rivai Wirasasmita, 1991. Pengendalian Biaya. Cetakan Pertama. Penerbit CV. Pionir Jaya Bandung. 